\title{
Fuel demand in Brazil in a dynamic panel data approach
}

\author{
Gervásio F. Santos * \\ Department of Economics, Federal University of Bahia, BA, Brazil \\ Regional and Urban Economics Lab (NEREUS), SP, Brazil
}

\section{A R T I C L E I N F O}

\section{Article history:}

Received 3 February 2009

Received in revised form 19 February 2012

Accepted 22 August 2012

Available online 31 August 2012

\section{Jel classification:}

C01

D12

L11

033

Q41

Q21

Keywords:

Fuel demand

Energy policy

Ethanol

Flex-fuel vehicle

Dynamic panel data model

\begin{abstract}
A B S T R A C T
The purpose of this paper is to evaluate the sensitivity of fuel consumers regarding price and income, taking recent changes in the Brazilian fuel market into account. In this market, new market rules, energy policy towards fuel diversification and introduction of flex-fuel engines have determined fuel competition among gasoline, ethanol and compressed natural gas. Using a dynamic panel data model, demand equations for these three fuels are econometrically estimated to obtain consumer adjustment coefficients, price, cross-price and income elasticities in the short and long-run. In addition, the effect of the introduction of flex-fuel engines in the market and the rationality of consumers towards efficiency constraints of the engines were tested. Apart from considerable competition, results show that the dynamics of the Brazilian fuel market revolves around ethanol instead of gasoline. While demands for gasoline and natural gas are inelastic to price, demand for ethanol is elastic in Brazil. Furthermore, after the introduction of the flex-fuel technology the sensitivity of consumers to fuel prices changed, and ethanol consumers take efficiency constrains into account when ethanol prices reach the threshold of $70 \%$ of gasoline prices.
\end{abstract}

(c) 2012 Elsevier B.V. All rights reserved.

\section{Introduction}

The Brazilian fuel market is considerably different from other markets due to diversity of alternative fuels. There are four main fuels in this market: gasoline, ethanol, natural gas - in its compressed form, thus known as compressed natural gas (CNG) - and diesel. Gasoline still remains as the main fuel, but it strongly competes with two substitutes: ethanol and CNG. The features of the Brazilian automobile fleet imply that diesel is only used by large road vehicles, not competing with other fuels in the short-run. Ethanol plays a historic role in the national energy policy, being an important alternative in periods of high oil prices or to face environmental enforcements. On the other hand, CNG has recently been introduced in the market and already competes with ethanol and gasoline. As a consequence of this diversified marked, the economic theory of consumer behavior suggests the hypothesis that consumers are more responsive to prices, and adjust faster towards desired demand levels. The estimation of price and income elasticities jointly with the adjustment coefficients of consumers might bring new insights about the Brazilian fuel market.

\footnotetext{
* Faculdade de Ciências Econômicas da UFBA, Praça 13 de Maio nํํ06, Piedade CEP. 40.070-010 - Salvador - Bahia - Brazil. Tel./fax: +55 7132837563.

E-mail address: gervasios@ufba.br.
}

The literature on the estimation of fuel demand equations in the field of energy economics is considerably extensive. Surveys of the literature might be found in Dahl (1995) and Dahl and Sterner (1991), which summarized a set of principles, models and data requirements used for the estimation of the demand for gasoline and transportation fuels. Bentzen (1994), Eltony and Al-Mutairi (1995), Espey (1996a, 1996b, 1998), Graham and Glaister (2002, 2004), Goodwin et al. (2004), and Polemis (2006) also provided good insights on this subject. The estimation of fuel demand through panel data models can be found in Baltagi and Griffin (1983), Puller and Greening (1999) and Rouwendal (1996). For the Brazilian fuel market Alves and Bueno (2003), Azevedo (2007), Burnquist and Bacchi (2002), Freitas and Kaneko (2011), Iootty et al. (2004), Nappo (2007), Pontes (2009), Rogat and Sterner (1998), Roppa (2005), Silva et al. (2009) and Schünemann (2007) estimated demand equations using time series models. General results for Brazil showed that fuel demand is inelastic and that these fuels are imperfect substitutes.

International and national literature reviews are focused on the estimation of gasoline demand and the usage of time series models. Dahl and Sterner (1991) presented standard models to estimate price and income elasticities for gasoline mainly using monthly, quarterly and yearly time series. Eltony and Al-Mutairi (1995) estimated the demand for gasoline in Canada and Kuwait, using cointegration techniques. Bentzen (1994) estimated the demand for gasoline in Denmark using 
that same technique. Dahl (1995) also presented a survey on demand elasticities and their components regarding the demand for transportation fuels. Espey (1996a) explained the variation in elasticity estimates of gasoline demand in the United States through meta-analysis. Espey (1996b) analyzed fuel consumption through an international automobile fuel-saving model. Espey (1998) wrote a review on gasoline demand through an international meta-analysis of elasticities. Graham and Glaister $(2002,2004)$ analyzed various international researches on the responses of conductors to fuel price changes and the road traffic-related elasticity estimates reported in international literature; particularly the magnitude of the relevant income and price effects and new directions in relevant literature. Goodwin et al. (2004) give the main results of a literature review of empirical studies that have been published since 1990, updating work on the effects of price and income on fuel consumption, traffic levels, and, where available, other indicators, including fuel efficiency and car ownership. More recently, Polemis (2006) presented the determinants of road energy demand in Greece using cointegration techniques and vector auto regression analysis. The evidence presented shows important differences between long- and short-run price elasticities.

In Brazil, the use of time series models with cointegration techniques to estimate the price and income elasticities prevails over other models, as shown in Table 1. Rogat and Sterner (1998) estimated the price and income elasticities of gasoline demand for some Latin American countries, including Brazil, to be compared to those of OECD countries. They concluded that Latin America tended to have a very heterogeneous pricing policy, which has not necessarily followed international trends. Burnquist and Bacchi (2002) estimated demand equations for gasoline in Brazil using yearly time series. The main finding was that fuel consumption is more sensitive to income than price in both the short and long-run. Alves and Bueno (2003) also estimated a demand equation for gasoline using yearly time series and found that ethanol is an imperfect substitute for gasoline, even in the long-run. Roppa (2005) compared the competitiveness of gasoline to that of ethanol, also using yearly time series. Results showed that ethanol is an imperfect substitute for gasoline, whose consumers are indifferent to price increases in both the short and long-run. Iootty et al. (2004) compared the competitiveness between gasoline and CNG using monthly time series and found that CNG is an imperfect substitute for gasoline. In spite of that, the demand for CNG was found to be price inelastic. In the short-run consumers were more sensitive to price than they were to income and in the long-run this relationship was shown to be inverted.

Recent studies in Brazil also have applied time series models and some of them have explored beyond gasoline demand. Azevedo (2007) estimated the short and long-run price, cross-price and income elasticity of ethanol and CNG demand in Brazil. Despite specific results showing that ethanol demand is almost elastic to its price and elastic to the gasoline price, the general result showed that price elasticities are growing in Brazil. Schünemann (2007) analyzed the gasoline demand in Brazil estimating its elasticities and the impact generated by the introduction of flex-fuel vehicles. General results showed a high income elasticity and only a very small effect of the flex-fuel vehicles on the long-run gasoline demand. The same kind of study was developed by Nappo (2007) and showed a considerable increase in the price elasticity of gasoline demand after the introduction of flex-fuel vehicles. Pontes (2009) estimated the ethanol demand and showed a considerable change in its price elasticities caused by the flex-fuel engines. Silva et al. (2009) studied the impact of the growing ethanol market on the demand elasticity for gasoline in Brazil and results showed a considerable increase in the price elasticity and cross-price elasticity regarding ethanol. Finally, Freitas and Kaneko (2011) analyzed the characteristics of ethanol demand in the context of fuel mix diversification in Brazil. The study showed that during the last decade, ethanol has strengthened its position as both an independent fuel and a substitute for gasoline. In summary, this study showed that the growth in the Brazilian automobile fleet based on flex-fuel technology is a major driving factor of long-run ethanol demand.

Previous studies in Brazil still present some limitations which the present study was designed to overcome. Few studies consider the substitution among the three main fuels. From the Brazilian literature review, only Silva et al. (2009) consider the use of econometric tools other than time series, but without the substitution among the three main fuels. The country-level estimations from aggregated time series might affect the results. The fuel market in Brazil presents specific features than those of other countries due to its diverse fuel supply. In addition to fuel diversification, the Brazilian economy is considerably heterogeneous and marked by a high degree of concentration of economic activity. For this reason, there are different unobserved heterogeneities at the state level that may affect consumer preferences to use each type of fuel. Panel data models can account for these heterogeneities and at the same time capture the variations among the time periods and the cross-section units. The consideration of these elements is the starting point to future studies in Brazil designed to evaluate different patterns of consumer behavior by region in the presence of fuel prices, income variations or fuel taxes. In addition, new market rules and technological advances in the automobile industry, such as flex-fuel engines, are increasing competition between fuels. For this reason, the question that emerges is: how sensitive are the consumers in this new environment? No previous study

Table 1

Short and long-run price, cross-price and income elasticities of the fuel demand in Brazil from the literature.

\begin{tabular}{|c|c|c|c|c|c|c|c|c|c|c|}
\hline \multirow[t]{3}{*}{ Reference $^{\mathrm{a}}$} & \multirow[t]{3}{*}{ Dependent variable $^{\mathrm{b}}$} & \multirow[t]{3}{*}{ Period } & \multicolumn{4}{|c|}{ Short-run } & \multicolumn{4}{|c|}{ Long-run } \\
\hline & & & \multicolumn{4}{|c|}{ Explanatory variables and elasticity $^{\mathrm{c}}$} & \multicolumn{4}{|c|}{ Explanatory variables and elasticity } \\
\hline & & & Gprice & Eprice & CNGprice & Income & Gprice & Eprice & CNGprice & Income \\
\hline Rogat and Sterner (1998) & Gasoline & 1960-1994 & & & & & & -0.980 & & 0.900 \\
\hline Burnquist and Bacchi (2002) & Gasoline & 1973-1998 & -0.319 & & & 0.600 & -0.230 & & & 0.960 \\
\hline Alves and Bueno (2003) & Gasoline & 1984-1999 & & & & 0.120 & -0.464 & 0.480 & & 0.122 \\
\hline Iootty et al. (2004) & CNG & $01.2001-12.2003$ & 0.100 & & -0.420 & 0.505 & 0.354 & & -1.010 & 0.181 \\
\hline Roppa (2005) & Gasoline & 1979-2003 & -0.073 & -0.198 & & 0.471 & -0.634 & 0.401 & & 0.163 \\
\hline Azevedo (2007) & Ethanol & $01.2002-06.2006$ & 1.301 & -0.926 & & 0.400 & -0.364 & -0.459 & & 0.137 \\
\hline Azevedo (2007) & CNG & $01.2002-06.2007$ & & 0.431 & & 0.394 & & & 0.247 & 0.406 \\
\hline Schünemann (2007) & Gasoline & 1980-2005 & -0.122 & & & 0.747 & -0.292 & & & 1.340 \\
\hline Schünemann (2007) & Gasoline & 01.1991-02.2007 & -0.488 & & & 0.857 & & -0.337 & & 1.749 \\
\hline Nappo (2007) & Gasoline & 08.1994-07.2006 & & & & & -0.197 & & & 0.690 \\
\hline Pontes (2009) & Ethanol & $7.2001-10.2008$ & & & & & 1.374 & -0.934 & & 1.255 \\
\hline Silva et al. (2009) & Gasoline & 04.2001-12.2006 & & & & & -0.945 & 0.049 & & 0.154 \\
\hline Freitas and Kaneko (2011) & Ethanol & $01.2003-07.2010$ & 1.987 & -1.800 & & & 0.948 & -1.413 & & \\
\hline
\end{tabular}

a References are ranked by the year of publication.

b Demand equation.

c Eprice, Gprice, CNGprice and income are real price of ethanol, gasoline, CNG and real income, respectively and the coefficients refer to elasticities in short and long-run. 


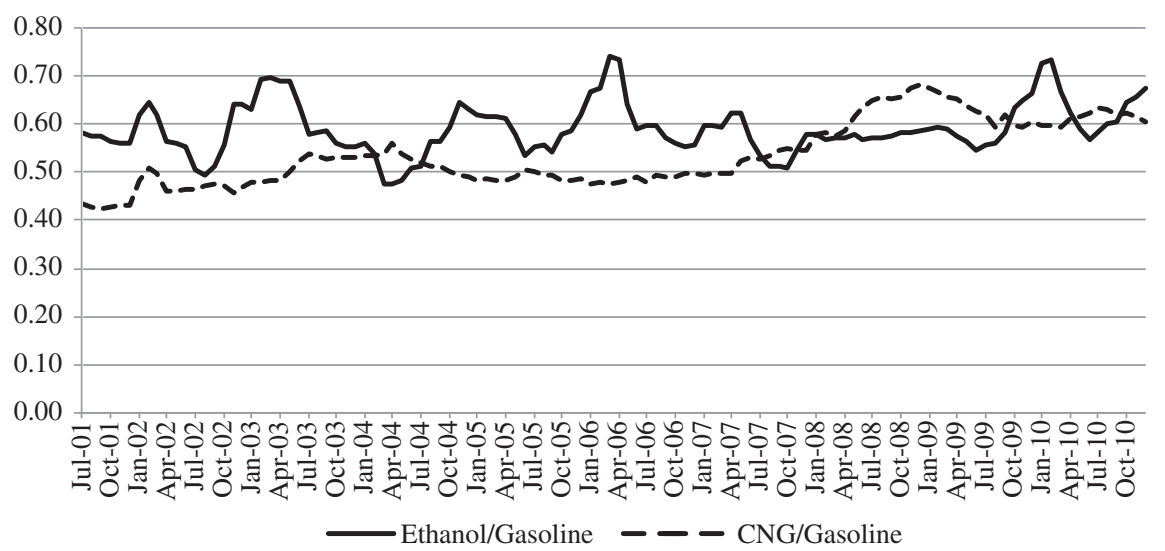

Fig. 1. Price relations in the Brazilian fuel market (Jul/2001-Dec/2010). Source: ANP - Brazilian National Agency of Oil and Biofuel.

examining the Brazilian fuel market has considered all factors identified. The present study is designed to overcome these shortcomings, introducing those elements in the analyses, along with a dynamic panel data approach to estimate fuel demand equations for Brazil.

The following section presents the main elements of the Brazilian fuel market, mainly the determinants of the new dynamics of the market. Section 3 presents the econometric specification to estimate demand equations for each fuel. In Section 4, the data requirements are described. The results and comparisons with previous studies will be presented in Section 5. Finally, in Section 6, some final remarks are presented.

\section{The Brazilian fuel market}

The starting point of the recent dynamics of the Brazilian fuel market was the liberalization process of this market in 1997. Through the known Law of Petroleum (Law 9.478/97) and new designs for energy policy, competition was introduced in the fuel market through free prices and free entry to new agents. The impacts of this policy on a market with considerable diversity of substitute and complementary fuels dramatically changed the structure of fuel demand in Brazil. In order to comprehend these changes, it is necessary to understand the cycle from the introduction of ethanol to the introduction of flex-fuel engines by the national automobile industry.

Ethanol was introduced in the Brazilian energy matrix in 1975 through the Pro Alcool or National Alcohol Program. This was a large scale energy production program designed to substitute ethanol produced from sugar cane for vehicular fossil fuel. ${ }^{1}$ The reasons for creating the program were the first and second oil shocks of 1974 and 1979 respectively. Likewise, the decision to produce ethanol from sugarcane was driven by low sugar prices in the international commodity market at that time. Since the beginning of Pro Alcool, ethanol fuel was massively introduced as a complementary and substitute fuel in Brazil. Initially, ethanol was mixed into gasoline, at an amount of $25 \%^{2}$ to this day (National Agency of Oil and Biofuel (ANP) (2011)). On the other hand, the Brazilian automobile industry has started to produce vehicles with engines that run solely on ethanol, making it also a substitute fuel to gasoline.

\footnotetext{
${ }^{1}$ The program was officially created in November 14th of 1975 by Decree no. 76.5930. Sugar-cane plantations and ethanol refineries were supported by the Government. Ethanol was priced at the rate of $65 \%$ of the gasoline price in 1980 and $59 \%$ in 1982. Moreover, prices of vehicles with ethanol engines and their property tax were set at $5 \%$ and $3 \%$ respectively, lower than taxes of vehicles with gasoline engines (Roppa).

2 Because of this mixture some authors refer to gasohol blend instead of gasoline fuel. In the remainder of the paper the international definition 'gasoline' will be used, even when considering its mixture.
}

The program was successful until the first half of the 1980s. After that, a set of factors such as the decline of oil prices (and consequently of gasoline) along with increases in sugar prices in the international market, led to the end of the program. In addition, the engagement of Brazil in liberal policies which enforced the elimination of subsidies made the program unfeasible. Aside from that, the production of ethanol and vehicles with ethanol engines continued on a small scale.

Regarding energy efficiency, because the calorific value of ethanol is smaller than that of gasoline, technical restrictions on engines result in fewer kilometers/hour using ethanol instead of gasoline. As a consequence, the competitiveness of ethanol in the Brazilian fuel market depends on its price being around $70 \%$ of the price of gasoline. In 1989, when the Pro Alcool program collapsed, this percentage was larger than $75 \%$ (Roppa, 2005). Since that time, the price relation has rigorously been maintained (Fig. 1), mainly due to government assistance, such as smaller fuel tax. ${ }^{3}$

The end of Pro Alcool in 1989 did not eliminate the use of ethanol as a fuel. A considerable fleet consuming ethanol still remained in the fuel market. The sales of vehicles with ethanol engines nonetheless declined from $80 \%$ of the total sales in the period $1983-1987$ to $0.7 \%$ in 2000. Data from the National Traffic Agency (DENATRAN) (2011) indicate that in 2009 the national fleet was composed of 35.5 million vehicles. About 25.4 million were light vehicles; from this amount 1.3 million ran solely on ethanol, which represented $5.1 \%$ of the light vehicle fleet. This stock of ethanol vehicles was important to the continuity and new developments in the technology of large scale ethanol production.

In the meantime, CNG was introduced in the fuel market. The initial strategy was to use it as a substitute for diesel in large road vehicles. However, given the logistical problems, the usage was restricted to large urban centers. In 1994, the implementation of a subsidy of $25 \%$ in Sao Paulo and $75 \%$ in Rio de Janeiro over the vehicle property tax for vehicles used in urban transportation services allowed for the creation of the first demand pool of CNG in Brazil. The CNG market rapidly increased in other regions of the country. In 2009, according to the Brazilian National Institute of Oil and Gas, there were 1.35 million vehicles powered by $\mathrm{CNG}^{4}$ Its low price relative to those of gasoline or ethanol, (Fig. 1) together with environmental concerns increased the CNG share in the fuel market in the last years (Roppa, 2005) (see also Fig. 5 in Appendix A).

\footnotetext{
${ }^{3}$ To subsidize ethanol and CNG, the tax named Contribution of Economic Domain has not been charged on these two fuels.

${ }^{4}$ Since the Brazilian automobile industry does not produce vehicles with CNG engines, a conversion process is necessary. As part of this process, a second tank is introduced in the vehicle. Because the original fuel tank is maintained, consumers may pump with a second fuel; gasoline or ethanol, depending on the original engine.
} 


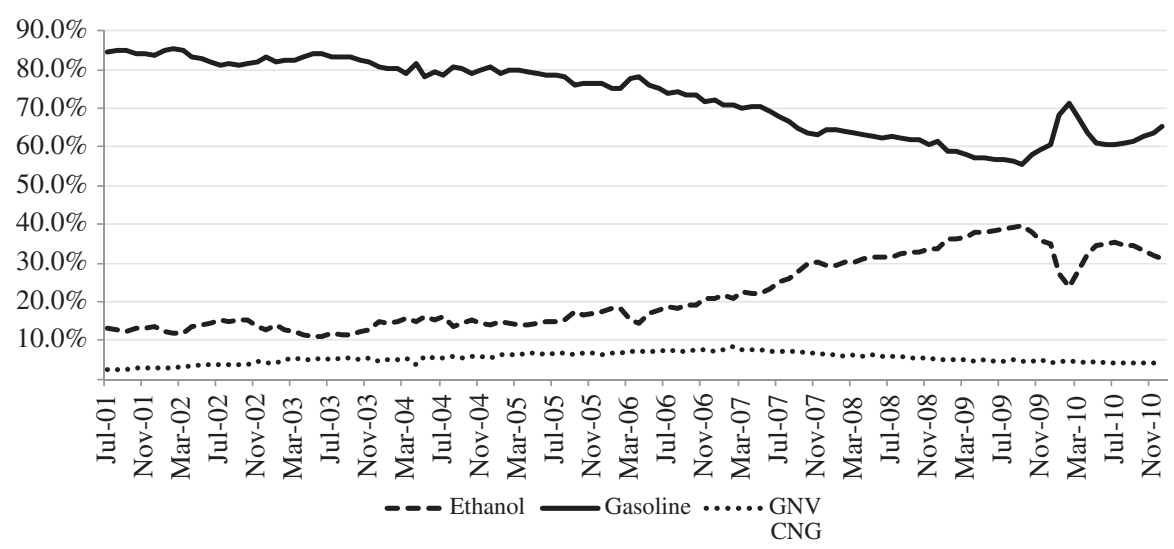

Fig. 2. Market share of gasoline, ethanol and CNG in Brazil (Jul/2001-Dec/2010). Source: ANP - Brazilian National Agency of Oil and Biofuel.

CNG increased the diversification in the fuel market ${ }^{5}$ for light vehicles. Fig. 2 shows the dynamics of this market after 2000. As can be seen, gasoline still remains as the main fuel, but the market share declined from $84.4 \%$ in 2001 to $65.2 \%$ in the end of 2010 . In the same period, the consumption of ethanol increased from $13.2 \%$ to $31.2 \%$ and CNG from $2.5 \%$ to $3.5 \%$. This might imply that consumers are close to desired demand levels in the gasoline market and distant in the other markets.

However, it should be noted that the recent increase in the demand for ethanol in Brazil results from a revolution in the automobile industry known as flex-fuel engines. ${ }^{6}$ This technology allows a vehicle to operate on gasoline, ethanol or CNG. It was developed in the United States in the 1980s and has been used in Brazil since the 1990s. In the end of 2003, it was introduced in the market through the bi-fuel vehicles, operating on ethanol or gasoline. In 2005, tri-fuel vehicles, which could operate on gasoline, ethanol, or CNG, were introduced in a very small scale in the market. In fact, the introduction of bi-fuel implied a radical structural change in the fuel market, which led gasoline producers and suppliers to adapt to a more competitive environment.

A first consequence of the new technology is that vehicle production has shifted away from ethanol or gasoline engines towards bi-fuel engines. As shown in Fig. 3, in 2005 the sales of vehicles with ethanol plus flex-fuel engines overcame those of gasoline engines. In 2010, the sales of light vehicles amounted to 3.57 million. From this amount, flex-fuel vehicles represented $81.2 \%$ ( 2.9 million, see in Fig. 4), diesel $10.6 \%$ and gasoline $8.2 \%$. On the other hand, vehicles with engines running solely on ethanol stopped being produced.

The changing trend in the production of vehicles and in the fleet composition increased the possibilities of choice by consumers. The obvious consequence, according to consumer economic theory is the greater sensitivity to fuel price. For this reason the estimation of demand equations for gasoline, ethanol and CNG will be carried, mainly due to its usefulness for international comparisons.

\section{Econometric specification}

Regarding Brazil, I have found thirteen main and unpublished published studies on fuel demand, summarized in Table 1 . The general results show that fuel demand in Brazil is inelastic and the fuels are imperfect substitutes. In addition, flex-fuel vehicles have influenced the estimated price elasticities of demand for fuel in the country.

\footnotetext{
${ }^{5}$ With the substitution of ethanol and CNG for gasoline and the high share of hydro power in Brazilian electricity production (83.2\%), 47.5\% of Brazilian electricity consumption comes from renewables. This share reduces energy dependence and vulnerability to high oil prices.

${ }^{6}$ This technology is embedded in the Poli-fuel engines trend of the world automobile industry.
}

Those previous studies present some shortcomings which the present study is designed to overcome. Most of these studies consider neither the substitution among the three fuels nor the use of econometric tools other than time series. Due to heterogeneity of the Brazilian economy the estimations from aggregated time series at the country level might affect the results. For those reasons, the parameters in Table 1 might be biased or not reflective of actual consumer behavior. Aside from this, after 2003, a radical change occurred in the market due to the introduction of the flex-fuel technology, whose impacts might be explained by a short-run analysis. The specification of demand equations using panel data might improve the results. For this reason, the present study intends to overcome these shortcomings through the estimation of price and income elasticities of fuel demand in Brazil using a quarterly panel dataset containing data on income, price and consumption of gasoline, ethanol and CNG. The use of panel data will allow controlling the unobserved heterogeneity regarding different patterns of fuel consumption among Brazilian states. Besides new parameters that can be compared to those of Brazil, we plan to provide considerable improvement to the international literature.

The first study on energy demand using panel data was developed by Balestra and Nerlove (1996). The authors estimated the demand for natural gas in the United States. Baltagi and Griffin (1983) estimated the demand for gasoline using panel data for OECD countries. Since that time, panel data models have been used increasingly in demand studies. Their theoretical principles can be found in Baltagi (2001), Hsiao $(1985,1986)$ and Wooldridge (2004).

In the present study, I assume that the demand is technologically dependent on the vehicles' engine. I will first consider that the market has no flex-fuel engines due to a large previous stock of non-flexible engines. The basic assumption is that consumers have some difficulty in changing to another fuel in the short-run and in the long-run. Therefore, previous consumption patterns determine those of the present. This modeling allows the estimation of the speed to which consumers adjust and whether this adjustment or other parameters change when a more flexible technology is introduced. To control the introduction of this new technology time dummies might be used.

The basic model is the partial adjustment model (Pesaran and Smith, 1995). Assuming a certain quantity of a good $\left(y_{i t}\right)$, its real price $\left(p_{g t}\right)$, the real price of a substitute good $\left(p_{s t}\right)$, the real per capita income $\left(I_{i t}\right)$ and the quantity of the same good in the previous last time $y_{i t-1}$, it is possible to obtain the formulation known for the lagged endogenous model:

$y_{i t}=f\left(p_{g t}, p_{s t}, I_{i t}, y_{i t-1}\right)$.

This model is easy to estimate, to interpret and does not overdemand data requirements, see Dahl and Sterner (1991). The lagged 


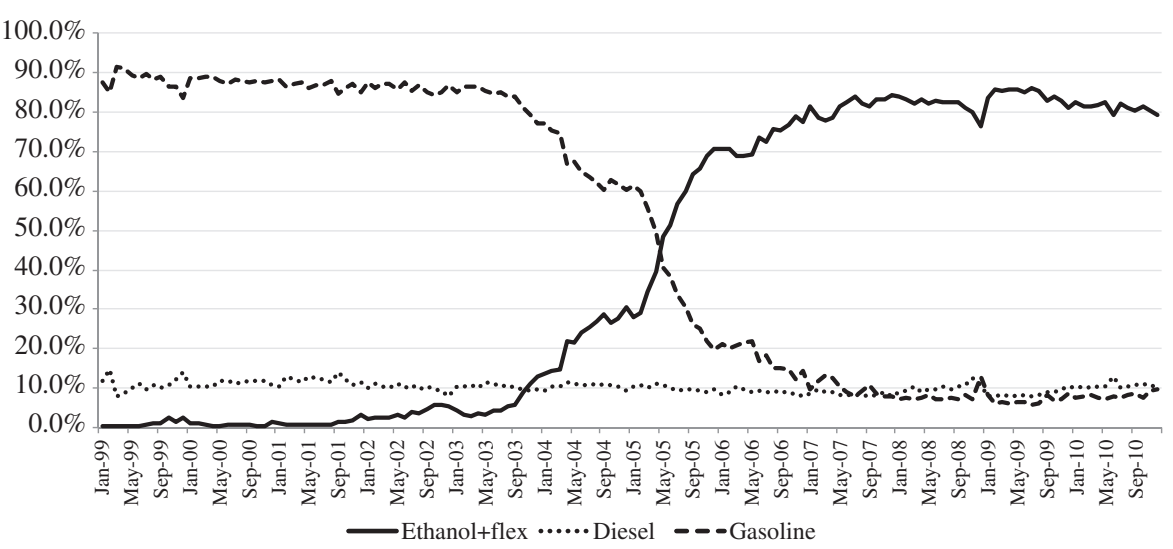

Fig. 3. Retail sales (quantity of vehicles) in Brazil by type of fuel (Jan/1999-Dec/2010). Source: Anfavea - Brazil's National Association of Vehicle Manufacturers.

dependent variable is a shortcut for inertia of economic behavior, deduced from assumptions about partial adjustments or adaptive expectations. There are two main theoretical interpretations about this assumption in the model. The first is that, for psychological, technological or institutional reasons, consumers do not change their habits immediately after changes in prices or income, because this may result in some level of disutility. I consider a delay in consumer reaction because consumption is not only a function of current income and price structures, but also of the past ones. Although this kind of specification seems to be from ad hoc models, ${ }^{7}$ the adequacy to theoretical foundations of consumer theory is the main stimulus to use it (see Liu, 2004).

Considering assumptions of partial adjustment and an autoregressive distributed lag (ADL) model in the form

$y_{i t}=\alpha+\sum_{i=1}^{p} \gamma_{i} y_{k, t-i}+\sum_{j=1}^{q} \beta_{k, j} x_{k, t-j}+u_{t}$.

In Eq. (2), $\gamma_{i}$ with $i=1, \ldots ., p$ are the coefficients of (autoregressive) lagged values of the dependent variable $y_{i t}, x_{k, t-j}$ with $j=0,1, \ldots ., q$ are the $k$-element column vectors of the current and distributed lagged values of explanatory variables, and $\beta_{k, j}$ is a column vector with $k$ coefficients, while $\alpha$ is the constant term and $u_{t}$ is the white noise error. The restrictions on lag length $p$ and $q$, which refer to the distribution of coefficients $\gamma_{i}$ and $\beta_{k, j}$, determine different $\operatorname{ADL}(p, q)$ models. In the present work the model that will be used is $\operatorname{ADL}(1,0)$.

Assume the equation

$y_{t}^{*}=\alpha_{0}+\alpha_{1} P_{g t}+\alpha_{2} P_{s t}+\alpha_{3} I_{t}+\varepsilon_{t} \quad \varepsilon_{t}^{\sim} I I D\left(0, \sigma^{2}\right)$

where $y_{t}^{*}$ is the unobserved desired level of demand in the period $t$, $P_{g t}, P_{s t}$ and $I_{t}$ and is the same as Eq. (1) and the $\alpha_{n}, n=0, \ldots ., 3$ are the parameters of the model. The relationship between $y_{t}^{*}$ and the actual demand $y_{t}$ is characterized by partial adjustment in consumer behavior. This adjustment is given by

$y_{t}-y_{t-1}=\theta\left(y_{t}^{*}-y_{t-1}\right)$

This specification states that changes in consumption during one period of time $\left(y_{t}-y_{t-1}\right)$ are a share of the difference between the desired demand in the current period and the actual demand in the previous period. The coefficient $\theta$ reflects the speed of adjustment towards the desired demand level and ranges in $[0,1]$. In other words, the larger the $\theta$ is, the faster the adjustment. For instance, if $\theta=1$, the actual demand immediately approaches the desired level. To

\footnotetext{
${ }^{7}$ For a discussion about different dynamic models of energy demand and the relationship among them, see Watkins (1991). And for an example which explicitly considers dynamic optimization over time, see Pindyck and Rotemberg (1982).
}

incorporate the speed of adjustment into the estimation process the $y_{t}^{*}$ from Eq. (4) might be inserted into Eq. (3). The rearrangement considering the specification for panel data model provides

$y_{i t}=\beta_{0}+\gamma y_{i(t-1)}+\beta_{1} P_{g(i t)}+\beta_{2} P_{s(i t)}+\beta_{3} I_{(i t)}+u_{(i t)}$.

In Eq. (5), $i=1, \ldots, N$ is the panel unit, $t=1, \ldots ., T$ is still the time period. The new parameters are: $\beta_{j}=\theta \alpha_{j}, j=0, \ldots, 3$ and $\gamma=(1-\theta)$ and. The endogenous error term now is $u_{i t}=\theta \varepsilon_{i t}$. The short-run price partial effects (or other interim periods until the long-run) are obtained by $\partial y_{t+k} / \partial p_{t}=\gamma^{k} \beta_{j}, k=0, \ldots, P$. Likewise, a long-run price effect may be expressed as $\sum_{k=1}^{P} \gamma^{k} \beta_{1}=\beta_{1} /(1-\gamma)$. At last, the linearization of the variables in the equation allows the elasticity in the short-run and long-run related to the relevant variable to be obtained. In this modeling, the presence of the lagged dependent variable improves the statistics and fit of models, mainly when there is no variable representing variation in vehicle stock.

In the panel specification in Eq. (5), it is assumed that there are unobserved time variant or invariant ${ }^{8}$ region-specific fixed effects $\mu_{i}$, mainly because of free market rules with no price control. Factors like the presence of oil refineries, natural gas production/infrastructure or ethanol production in different regions are examples of fixed effect elements which might influence price through transportation costs. In the same way, different regional incomes per capita levels might influence the choice of the fuel and the sensitivity of the parameters. In addition, unobserved random effects may also affect the fuel demand and must be considered.

To include the factors above in the model, take $\mu_{i}$ being a fixed parameter of a random variable and the error component expressed as

$u_{(i t)}=\mu_{i}+\eta_{(i t)}$, being $\mu_{i}^{\sim} I I D\left(0, \sigma_{\mu}^{2}\right)$ and $\eta_{(i t)} \sim \operatorname{IID}\left(0, \sigma_{\eta}^{2}\right)$.

The term $\eta_{i t}$ now represents the reminder error term. The new statistic assumptions are:

$E\left(P_{g(i t)}, \mu_{i}\right) \neq 0 ; E\left(P_{s(i t)}, \mu_{i}\right) \neq 0 ; E\left(I_{(i t)}, \mu_{i}\right) \neq 0$.

The terms in Eq. (7) express the correlation between the unobserved time invariant region-specific effect and all the explanatory variables of the model. Finally, since $y_{(i t)}$ is a function of $\mu_{i}$ and $y_{(i t-1)}$ also is a function of $\mu_{i}$, an endogeneity problem must be considered in the estimation, even if $\eta_{i t}$ is not serially correlated (see Nickell, 1981).

Considering the presence of the lagged dependent variable, since $y_{i t}$ is a function of $\mu_{i}$, it follows that $y_{i t-1}$ is also a function of $\mu_{i}$. For

\footnotetext{
${ }^{8}$ The argument to be time invariant accounts mainly because of short-run period considered.
} 


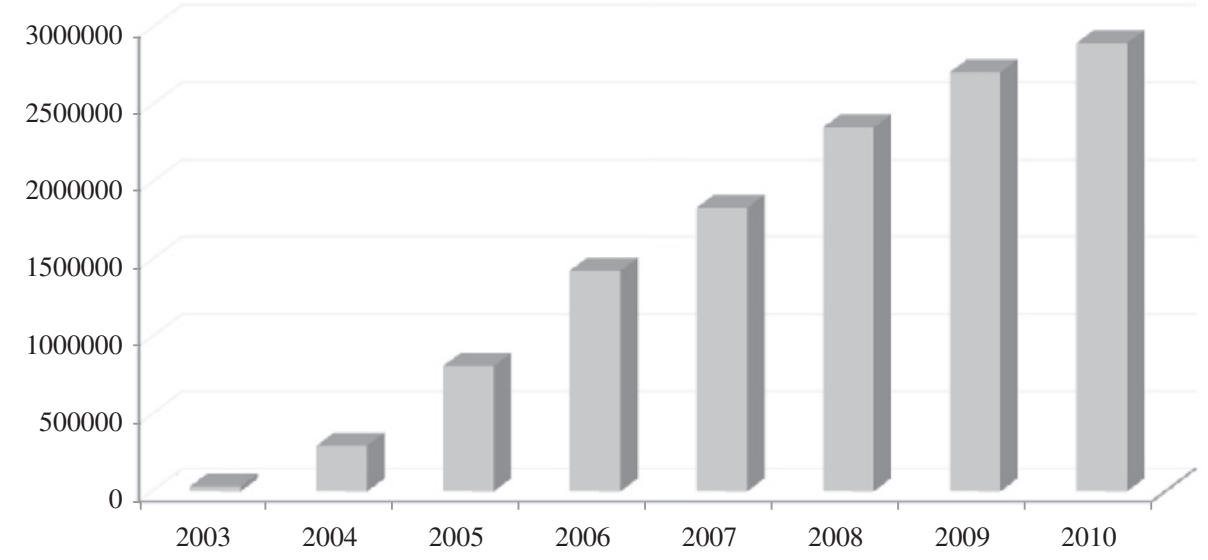

Fig. 4. Retail sales (quantity of vehicles) of flex-fuel vehicles Brazil (2003-2010). Source: Anfavea - Brazil's National Association of Vehicle Manufacturers.

this reason, $y_{i t-1}$ in the right hand side of Eq. (5) is correlated with the error term. As a consequence, OLS estimation may be biased and inconsistent. The estimation using SUR would not account for $\mu_{i}$. The fixed effect estimator would eliminate $\mu_{i}$, but does not account for endogeneity problems. Therefore, I use the GMM estimator from Arellano and Bond (1991) (see Baltagi, 2001 and Wooldridge, 2004).

The first step to solve the endogeneity problem aforementioned was given by Anderson and Hsiao (1981, 1982), who suggested first differencing Eq. (5) to remove the $\mu_{i}$ and then using $\Delta y_{i t-2}=$ $\left(y_{i t-2}-y_{t-3}\right)$ or $y_{t-2}$ as an instrument for $\Delta y_{i t-1}=\left(y_{i t-1}-y_{t-2}\right)$. The instruments will not be correlated with $\Delta \eta_{i t}=\left(\eta_{i t}-\eta_{i t-1}\right)$, since $\eta_{i t}$ are not serially correlated themselves. According to Baltagi (2001), the application of the instrumental variable (IV) estimation method using these instruments leads to consistent but not necessarily efficient estimates of the parameters in the model.

In addition, Arellano and Bond (1991) proposed a generalized method of moments (GMM) procedure, based on the Anderson and Hsiao procedure to find instruments, but considered to be more efficient. Also known as dynamic panel data estimator, instead of using pooled IV with instruments $\Delta y_{i t-2}$ or $y_{t-2}$, Arellano and Bond proposed using the entire set of instruments, which require the GMM estimation. The basis of GMM is the specification of a set of population moment conditions and, for this reason, the entire set of instruments might be used. Thus, by utilizing the orthogonality conditions that exist between lagged values of $y_{i t}$ and the disturbances $\eta$, the method can generate consistent estimates when the number of panel data units $N$ and/or the time $T$ goes to infinity (Baltagi, 2001). At the same time, it also eliminates the unobserved fixed effect and resolves some possible endogeneity problem that might arise in the price variables of the demand equation. The validity of instrumental variables can be tested using the Sargan test of over identifying restrictions, developed by Sargan (1958). The hypothesis being tested is that the instrumental variables are uncorrelated to some set of residuals, and therefore they are acceptable instruments. On the other hand, the Arellano and Bond test might be used to test for the existence of zero autocorrelation in first-differenced errors.

\section{Data requirements, unit root and panel cointegration}

After the estimation of equations, this section presents the particularities of the data and the results for the unit root and cointegration tests.

The three demand equations to be estimated are:

$$
\begin{aligned}
\ln G_{(i t)}= & \beta_{0}+\gamma \ln G_{(i t-1)}+\beta_{1} \ln P_{G(i t)}+\beta_{2} \ln P_{E(i t)}+\beta_{3} \ln P_{C N G(i t)} \\
& +\beta_{4} \ln G D P_{(i t)}+u_{(i t)}
\end{aligned}
$$

$$
\begin{aligned}
\ln E_{(i t)}= & \beta_{0}+\gamma \ln E_{(i t-1)}+\beta_{1} \ln P_{G(i t)}+\beta_{2} \ln P_{E(i t)}+\beta_{3} \ln P_{C N G(i t)} \\
+ & \beta_{4} \ln G D P_{(i t)}+u_{(i t)} \\
\ln C N G_{(i t)}= & \beta_{0}+\gamma \ln C N G_{(i t-1)}+\beta_{1} \ln P_{G(i t)}+\beta_{2} \ln P_{E(i t)} \\
& +\beta_{3} \ln P_{C N G(i t)}+\beta_{4} \ln G D P_{(i t)}+u_{(i t)} .
\end{aligned}
$$

The three dependent variables will be the per capita consumption of gasoline $(G)$, ethanol $(E)$ and $C N G$. The other explanatory variables are: real prices of gasoline $\left(P_{G}\right)$, ethanol $\left(P_{E}\right)$ and $C N G\left(P_{C N G}\right)$ and per capita gross domestic product $(G D P)$.

A quarterly panel dataset from 27 Brazilian state economies for the period ranging from Jul/2001 to Dec/2010 was built. This was the period in which ANP surveyed data about fuel prices and consumption. The whole dataset is composed of 1026 observations. After eliminating regions and periods with no data about CNG, the sample was reduced to 634 observations. The price index and population data were obtained from the Brazilian Institute of Geography and Statistics (IBGE) (2011). Since there is no quarterly data of GDP (income) by state, a proxy variable had to be used. The variable used was the Tax on Trade of Products and Services (ICMS) obtained from the Brazilian National Treasury (2011). To avoid the endogeneity problem the fuel tax was excluded from ICMS. This tax is charged on the final commercialization of all products and services in Brazil and is directly passed on to the final consumer in all Brazilian states when the consumer buys products and services. For this reason, this tax is a proxy that captures the direct increase or decrease of income in each state of Brazil, considering that the increase or decrease in consumption is a direct effect of the same variation in income.

Regarding the use of stock of vehicles and the prime interest rate as explanatory variables, some comments need to be addressed. There is no quarterly public data about the stock of vehicles by state and fuel in Brazil. This problem becomes more complex because of the large recent amount of flex-fuel vehicles that affect the gasoline or ethanol demand and the large amount of vehicles converted to CNG that might also be pumped with ethanol or gasoline. For this reason, the lagged dependent variable continues to be the best strategy to minimize possible problems. On the other hand, the prime interest rate could also be used as an explanatory variable to indicate the level of economic activities. However, this is a macroeconomic variable, with no variation among the panel units and with lagged effects on economic activity. Since panel data is available and the Brazilian fuel market is considerably competitive, quarterly variables of fuel prices and income are sufficient to explain fuel consumption. In case possible endogeneity biases arise, the GMM method minimizes them. This method also solves the problems of possible endogeneity of fuel prices such as the link between gasoline prices and oil prices, 
Table 2

Westerlund cointegration tests for the gasoline demand variables.

\begin{tabular}{llrl}
\hline Statistic & Value & Z-value & P-value \\
\hline $\mathrm{Gt}$ & -1.255 & 2.304 & 0.989 \\
$\mathrm{Ga}$ & -0.958 & 5.701 & 1.000 \\
$\mathrm{Pt}$ & -10.419 & -2.728 & 0.003 \\
$\mathrm{~Pa}$ & -3.964 & 0.252 & 0.600 \\
\hline
\end{tabular}

and the link between ethanol prices and sugar prices which also are both unavailable for the panel units used in this paper.

Because of the considerable extension of the time period in the panel, with $T=38$, unit root and cointegration tests need to be performed. I applied the unit root tests of Breitung (2000), Breitung and Das (2005), Harris and Tzavalis (1999), Im et al. (2003) (Im-Pesaran-Shin test), Levin et al. (2002) (Levin-Lin-Chu test), Choi (2001) - (Fisher-type) and Hadri (2000) (Lagrange Multiplier (LM) test). The last two tests have, respectively the null hypothesis that all the panels have a unit root and are (trend) stationary. It should be noted that, while for CNG consumption and price, which are unbalanced panels, the Im-PesaranShin and the Fisher-type tests allow for unbalanced panels. In addition the Westerlund (2007) error-correction-based cointegration tests for panel data were applied. Because of the large amount of unit root tests for each variable, only the cointegration tests were reported in the paper.

For the consumption and price variables, the null hypothesis of a unit root for the entire panel was rejected in all the tests considering the presence of a trend in the series. However, the Hadri LM test showed that for some individual panels there was evidence of unit root. The same result was verified for the income proxy variable. In this context, because of the dynamic panel data GMM method is applied on the variables in differences, possible problems are minimized. Because the four cointegration tests of Westerlund require a balanced panel, this text was carried out for the ethanol and gasoline demand excluding the CNG price variable, which is an unbalanced panel. Tables 2 and 3 present the results for the tests considering a maximum of 3 lags.

As shown in Tables 2 and 3, according to the Westerlund (2007) statistic tables, results do not reject the hypothesis that the series are not cointegrated. Different lag structures were tested and the results remained robust. There is no stable long-term equilibrium among the variables and the equations could not be estimated in level, but in difference, what reinforces the use of the dynamic panel data GMM estimation, that takes the differences of the variables. On the other hand, long-run relationships cannot be estimated.

\section{Estimation, results and comparisons}

In order to evaluate the sensitivity of consumers to recent changes in the Brazilian fuel market, in the first step, the adjustment coefficients, short-run price, cross-price and income elasticities were obtained through the estimation of demand in Eqs. (8) to (10) in logarithm for each competing fuel, using the Stata package. In addition, long-run elasticities were calculated. In the second step, dummy variables were introduced to evaluate the effects of flex-fuel engines in the market, as well as if the consumers obey thresholds of prices given by technical restrictions of engines.

Tables 4, 5 and 6 present the one-step GMM estimations for the elasticities $\varepsilon_{(.)}$, the cross-price elasticities $\varepsilon_{(. . .)}$, coefficient of the lagged dependent variable $\gamma$, and the adjustment coefficients $\theta_{(.)}$of the three demand equations. For each equation, eleven estimations were carried out. After estimation 1 of each equation, the additive and multiplicative time dummy variables dflex were included. From estimations 2 to 6 , additive and multiplicative time dummy variables, equal to 1 for all quarters after December 2003, were introduced to evaluate the impact of the introduction of flex-fuel vehicles on the elasticities.
Table 3

Westerlund cointegration tests for the ethanol demand variables.

\begin{tabular}{llll}
\hline Statistic & Value & Z-value & P-value \\
\hline $\mathrm{Gt}$ & -0.969 & 3.757 & 1.000 \\
$\mathrm{Ga}$ & -0.600 & 5.999 & 1.000 \\
$\mathrm{Pt}$ & -2.992 & 2.938 & 0.998 \\
$\mathrm{~Pa}$ & -0.794 & 2.860 & 0.998 \\
\hline
\end{tabular}

From estimations 7 to 11, the additive and multiplicative dummy variables $d t h r$, which equal 1 when ethanol prices cross the threshold of $70 \%$ of gasoline prices and 0 otherwise, were introduced to evaluate the rationality of the consumers regarding technical limitations of flex-fuel engines.

For all three equations, the Sargan test led to the rejection of the hypothesis of over-identification restriction for the estimation. This makes the dependent variables the valid instrumental variables to estimate the model. In addition, also for the three equations, the Arellano-Bond test led to a non-rejection of the hypothesis of no serial autocorrelation in residuals. After these estimations, the short-run elasticities which were also estimated using the Translog function were compared. These estimations are presented in Table 8 of Appendix B.

\subsection{Gasoline}

Results for the gasoline demand equation are supported by economic theory. The short-run price-elasticity of -0.399 had the expected sign and is close to Burnquist and Bacchi's (2002) estimation of -0.319 and -0.488 of Schünemann (2007) in Table 1. This value also is considerably close to Dahl and Sterner's (1991) estimate. The cross-price elasticity of ethanol of 0.099 also had the expected sign and was not close to other estimations for Brazil such as those of Roppa (2005). However, the cross-price elasticity regarding CNG of 0.009 had the expected sign but was not so statistically significant; there is no estimate in the literature to make a comparison. Although a proxy was used to GDP per capita, the income elasticity of 0.176 was close to Alves and Bueno's (2003) estimate. The general result for gasoline demand shows that gasoline and ethanol are imperfect substitutes in Brazil. These two fuels are strongly competing in the fuel market. The adjustment coefficient of 0.336 is far from 1 and indicates that in the short-run the demand for gasoline is not close to desired demand levels. ${ }^{9}$ Regarding the estimations using the Translog function in Table 8 , the price and cross-price elasticities were considerably higher and also distant from the present dynamic model.

For estimations (2) to (6) in Table 4, the additive and multiplicative time dummy variable dflex was introduced. Results in estimation (2) show that the introduction of the additive dummy led to a small moving up of the gasoline demand curve, from -0.170 to $-0.049=(-0.0220)+(-0.0270)$ at the intercept. From estimation (3) to estimation (6), despite the non significance of the cross-price elasticity of ethanol and CNG in Eq. (4), the results of the introduction of multiplicative dflex dummy are similar to Schünemann's (2007) results and show that there was no relevant change in price elasticities of gasoline demand after December 2003. Price elasticity decreased from -0.399 to $-0.393=(-0.353)+(-0.040)$, the cross price elasticity with respect to CNG increased from 0.009 to $0.041=$ $(-0.063)+(0.104)$ and income elasticity from 0.176 to $0.205=$ $(0.198)+(0.006)$. This result is possibly affected by the fact that gasoline consumers belong to the highest income categories in Brazil and also because only 10 of the 38 quarters of the database used in the estimations represented the period previous to the introduction of flex-fuel

\footnotetext{
${ }^{9}$ Pesaran and Smith (1995) pointed out the bias of the adjustment coefficient when adjustment coefficient is close to 1 . In the present study, the wide ranges of this coefficient among the estimated equations lead to the conclusion that the bias did not exist.
} 
Table 4

One-step GMM-Arellano-Bond short-run estimation of gasoline demand for Brazil.

\begin{tabular}{|c|c|c|c|c|c|c|c|c|c|c|c|}
\hline Parameters & (1) & (2) & (3) & $(4)$ & (5) & (6) & (7) & $(8)$ & (9) & (10) & (11) \\
\hline Constant & $\begin{array}{l}-0.170^{*} \\
(0.087)\end{array}$ & $\begin{array}{l}-0.022^{*} \\
(0.102)\end{array}$ & $\begin{array}{l}-0.082^{*} \\
(0.096)\end{array}$ & $\begin{array}{l}-0.240^{*} \\
(0.089)\end{array}$ & $\begin{array}{l}-0.099^{*} \\
(0.089)\end{array}$ & $\begin{array}{c}-0.066^{*} \\
(0.0974)\end{array}$ & $\begin{array}{l}-0.217^{*} \\
(0.089)\end{array}$ & $\begin{array}{l}-0.185^{*} \\
(0.088)\end{array}$ & $\begin{array}{l}-0.168^{*} \\
(0.086)\end{array}$ & $\begin{array}{l}-0.119^{*} \\
(0.088)\end{array}$ & $\begin{array}{l}-0.198^{*} \\
(0.088)\end{array}$ \\
\hline$\varepsilon_{g}$ & $\begin{array}{l}-0.399^{*} \\
(0.070)\end{array}$ & $\begin{array}{l}-0.378^{*} \\
(0.070)\end{array}$ & $\begin{array}{l}-0.353^{*} \\
(0.073)\end{array}$ & $\begin{array}{l}-0.428^{*} \\
(0.070)\end{array}$ & $\begin{array}{l}-0.373^{*} \\
(0.070)\end{array}$ & $\begin{array}{l}-0.379^{*} \\
(0.0706)\end{array}$ & $\begin{array}{l}-0.318^{*} \\
(0.078)\end{array}$ & $\begin{array}{l}-0.368^{*} \\
(0.075)\end{array}$ & $\begin{array}{l}-0.416^{*} \\
(0.072)\end{array}$ & $\begin{array}{l}-0.427^{*} \\
(0.071)\end{array}$ & $\begin{array}{l}-0.335^{*} \\
(0.078)\end{array}$ \\
\hline$\varepsilon_{g . e}$ & $\begin{array}{l}0.099 * \\
(0.040)\end{array}$ & $\begin{array}{l}0.096^{*} \\
(0.039)\end{array}$ & $\begin{array}{l}0.097^{*} \\
(0.040)\end{array}$ & $\begin{array}{l}-0.029^{\mathrm{ns}} \\
(0.056)\end{array}$ & $\begin{array}{l}0.098^{*} \\
(0.039)\end{array}$ & $\begin{array}{l}0.0953^{*} \\
(0.039)\end{array}$ & $\begin{array}{l}0.019^{*} \\
(0.052)\end{array}$ & $\begin{array}{l}0.059^{\text {ns }} \\
(0.052)\end{array}$ & $\begin{array}{l}0.134^{*} \\
(0.054)\end{array}$ & $\begin{array}{l}0.144^{*} \\
(0.042)\end{array}$ & $\begin{array}{l}0.036^{\mathrm{ns}} \\
(0.051)\end{array}$ \\
\hline$\varepsilon_{\text {g.cng }}$ & $\begin{array}{l}0.009^{\mathrm{ns}} \\
(0.019)\end{array}$ & $\begin{array}{l}0.021^{\mathrm{ns}} \\
(0.019)\end{array}$ & $\begin{array}{l}0.018^{\mathrm{ns}} \\
(0.019)\end{array}$ & $\begin{array}{l}0.006^{\mathrm{ns}} \\
(0.019)\end{array}$ & $\begin{array}{l}-0.063^{*} \\
(0.029)\end{array}$ & $\begin{array}{l}0.0192^{\mathrm{ns}} \\
(0.0191)\end{array}$ & $\begin{array}{l}0.009^{\mathrm{ns}} \\
(0.019)\end{array}$ & $\begin{array}{l}0.010^{\mathrm{ns}} \\
(0.019)\end{array}$ & $\begin{array}{l}0.008^{\mathrm{ns}} \\
(0.019)\end{array}$ & $\begin{array}{l}-0.069^{*} \\
(0.032)\end{array}$ & $\begin{array}{l}0.009^{\mathrm{ns}} \\
(0.019)\end{array}$ \\
\hline$\varepsilon_{I}$ & $\begin{array}{l}0.176^{*} \\
(0.027)\end{array}$ & $\begin{array}{l}0.210^{*} \\
(0.030)\end{array}$ & $\begin{array}{l}0.201^{*} \\
(0.029)\end{array}$ & $\begin{array}{l}0.158^{*} \\
(0.027)\end{array}$ & $\begin{array}{l}0.200^{*} \\
(0.028)\end{array}$ & $\begin{array}{l}0.1983^{*} \\
(0.028)\end{array}$ & $\begin{array}{l}0.180^{*} \\
(0.027)\end{array}$ & $\begin{array}{l}0.178^{*} \\
(0.027)\end{array}$ & $\begin{array}{l}0.174^{*} \\
(0.027)\end{array}$ & $\begin{array}{l}0.193^{*} \\
(0.027)\end{array}$ & $\begin{array}{l}0.181^{*} \\
(0.027)\end{array}$ \\
\hline$\Gamma$ & $\begin{array}{l}0.664^{*} \\
(0.028)\end{array}$ & $\begin{array}{l}0.671^{*} \\
(0.028)\end{array}$ & $\begin{array}{l}0.668^{*} \\
(0.028)\end{array}$ & $\begin{array}{l}0.655^{*} \\
(0.028)\end{array}$ & $\begin{array}{l}0.666^{*} \\
(0.028)\end{array}$ & $\begin{array}{l}0.6714^{*} \\
(0.028)\end{array}$ & $\begin{array}{l}0.656^{*} \\
(0.029)\end{array}$ & $\begin{array}{l}0.661^{*} \\
(0.028)\end{array}$ & $\begin{array}{l}0.663^{*} \\
(0.028)\end{array}$ & $\begin{array}{l}0.659^{*} \\
(0.028)\end{array}$ & $\begin{array}{l}0.659^{*} \\
(0.028)\end{array}$ \\
\hline $\begin{array}{l}\Theta=(1-\gamma) \\
D \text { flex }\end{array}$ & 0.336 & $\begin{array}{l}0.329 \\
-0.027^{*} \\
(0.010)\end{array}$ & 0.332 & 0.345 & 0.334 & 0.329 & 0.344 & 0.339 & 0.337 & 0.341 & 0.341 \\
\hline Dflexpgsil & & & $\begin{array}{l}-0.040^{*} \\
(0.019)\end{array}$ & & & & & & & & \\
\hline Dflexpalcl & & & & $\begin{array}{l}0.173^{*} \\
(0.054)\end{array}$ & & & & & & & \\
\hline Dflexpcng & & & & & $\begin{array}{l}0.104^{*} \\
(0.033)\end{array}$ & & & & & & \\
\hline Dflexincome & & & & & & $\begin{array}{l}0.0063^{*} \\
(0.0028)\end{array}$ & & & & & \\
\hline Dthr & & & & & & & $\begin{array}{l}0.023^{*} \\
(0.010)\end{array}$ & & & & \\
\hline Dthrpgsls & & & & & & & & $\begin{array}{l}0.024^{\mathrm{ns}} \\
(0.020)\end{array}$ & & & \\
\hline Dthrpalc & & & & & & & & & $\begin{array}{l}-0.046^{\mathrm{ns}} \\
(0.048)\end{array}$ & & \\
\hline Dthrpcng & & & & & & & & & & $\begin{array}{l}0.114^{*} \\
(0.037)\end{array}$ & \\
\hline Dthrincome & & & & & & & & & & & $\begin{array}{l}-0.005^{*} \\
(0.003)\end{array}$ \\
\hline Observations & 592 & 592 & 592 & 592 & 592 & 592 & 592 & 592 & 592 & 592 & 592 \\
\hline Wald-prob $>\chi^{2}$ & 0.000 & 0.000 & 0.000 & 0.000 & 0.000 & 0.000 & 0.000 & 0.000 & 0.000 & 0.000 & 0.000 \\
\hline
\end{tabular}

Note 1: The values in brackets refer to standard error.

Note 2: The symbols “*”, “**” and “***” refer to significance level at $1 \%, 5 \%$ and $10 \%$ respectively and "ns” refers to a non-significant parameter.

engines. For this reason, a longer panel data, regarding time units, starting considerably distant from December 2003, would be necessary to capture the entire effect.

Regarding estimations ( 7 ) to (11), the additive and multiplicative dummy variable $d t h r$ was introduced. Results in estimation (7) show that the introduction of an additive dummy led to a small downward shift in the gasoline demand equation, going from -0.170 to $-0.194=(-0.217)+(0.023)$ at the intercept. Finally, results in estimations (8) to (11), regarding the introduction of the multiplicative dummy $d$ thr, also show that there was no relevant change in elasticities of the demand for gasoline when ethanol prices reached the threshold of $70 \%$ of gasoline prices.

\subsection{Ethanol}

Table 5 presents results of the ethanol demand equation. They were fully supported by economic theory, although this is not so common for the energy economics literature. The negative, high and greater than 1 price-elasticity of -1.252 is close to Azevedo's (2007) estimate and shows that consumers of ethanol in Brazil are price-elastic in the short-run. This result is not so common for energy goods, which usually are price-inelastic. This reflects a combination of factors such as the consumers coming from smaller income groups and being attracted by cheaper fuel and the introduction of flex-fuel engines in the market. The high cross-price elasticity regarding gasoline of 1.182 also is close to Azevedo's (2007) estimate and can be due to strong competition between ethanol and gasoline. It also suggests that gasoline prices are more important for ethanol demand than for the demand for gasoline. The cross-price elasticity regarding CNG of 0.098 implies that there is little competition between ethanol and CNG. The income elasticity of
0.551 is considerably greater than that of gasoline demand and very close to Azevedo's (2007) estimate. At last, the adjustment coefficient of 0.148 suggests that ethanol consumers are distant from the desired demand level, i.e., it is possible for the ethanol market to increase even more rapidly in Brazil. The results of the Translog estimation, in Table 8 , show that although the price and cross-price elasticity with respect to ethanol are very close, they are not significant, and the cross-price with respect to CNG and income elasticity are distant from the dynamic model.

The results of the additive time dummy variable dflex in estimation (2) show that the introduction of an additive dummy led to a small downward shift of the ethanol demand equation from 0.701 to $0.429=(0.359)+(0.069)$, at the intercept. From estimation (3) to estimation (6) results for the multiplicative dummy only show minor decreases in the price elasticity from -1.252 to $-1.234=$ $(-1.311)+(0.077)$, in the cross-price elasticity with respect to gasoline from 1.182 to $1.162=(1.02)+(0.14)$, in the cross-price elasticity with respect to CNG from 0.098 to $0.038=(0.229)+(-0.190)$, and in the income elasticity from 0.551 to $0.464=(0.483)+(-0.019)$. I hoped there would be an increase in elasticities, but once again this may possibly be a result of the fact that only 10 quarters in the database represent the period prior to the introduction of flex-fuel engines. The high price elasticities already are an effect of flex-fuel engines.

The additive dummy variable $d t h r$ in estimation (7) shows that after prices of ethanol reach $70 \%$ of those of gasoline, there is a small upward shift of the ethanol demand equation from 0.701 to $0.770=$ $(0.854)+(-0.084)$ at the intercept. Results in estimations (8) to (11), regarding the introduction of the multiplicative dummy dthr, show a considerable increase in price elasticity from -1.252 to 
Table 5

One-step GMM-Arellano-Bond short-run estimation of ethanol demand for Brazil.

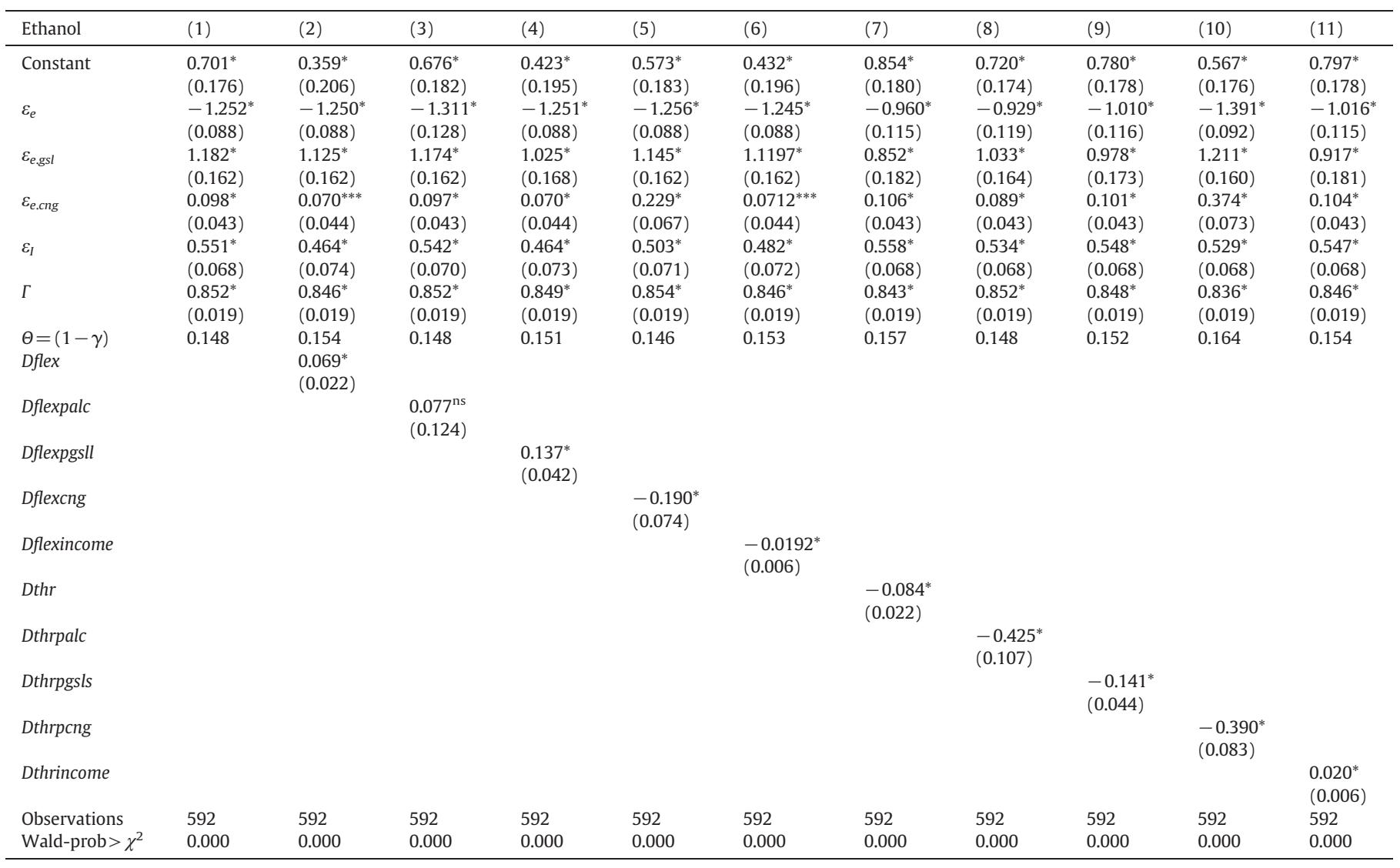

Note 1: The values in brackets refer to standard error.

Note 2: The symbols “*”, “**” and “***" refer to significance level at $1 \%, 5 \%$ and $10 \%$ respectively and "ns" refers to a non-significant parameter.

$-1.354=(-0.929)+(-0.425)$, a decrease in cross-price with respect to gasoline from $1.182=(0.978)+(-0.141)$ and a small increase in income elasticity from 0.551 to $0.568=(0.547)+(0.020)$, which are expected results. However, there was an unexpected result of the declining and reversion of the cross-price elasticity with respect to CNG. This might be evidence that when ethanol prices are considerably high the consumption of this fuel is relegated to owners of used cars whose engines run solely on ethanol but were also converted to use CNG, and for this reason an increase in CNG prices leads to a decrease in its demand and in ethanol demand.

\section{3. $C N G$}

Results for the CNG demand equation are presented in Table 6. They are supported by economic theory. Comparing to Iootty et al. (2004) in Table 1 , the estimated price elasticity of -0.178 is less than half of the value of -0.420 , the cross-price with respect to gasoline of 0.371 is more than three times greater than the value of 0.100 and the income elasticity of 0.139 is more than three times smaller than the value of 0.510 . The cross-price with respect to ethanol is not significant. It is possible to observe that, despite these comparisons, the elasticities for this equation are considerably small. In Brazil, CNG consumers usually belong to lower income groups and/or are owners of older used vehicles whose engines were converted from gasoline or ethanol to also run on CNG. And since CNG prices are maintained artificially low to stimulate the market, consumers are not so sensible to price and income. In addition, since CNG might be considered an inferior fuel in Brazil, this suggests that it should not be estimated by using the SUR model, for example. The adjustment coefficient of 0.172 is distant to one and means that the CNG consumption in Brazil is distant from the desired demand level. Finally, the results of the Translog estimation are very low, following the same pattern as the dynamic model, but only the income elasticity is significant.

The introduction of the additive time dummy variable dflex in estimation (2) led to a downward shift of the demand equation from -1.017 to $-1.454=(-1.526)+(0.073)$ at the intercept. As shown in estimations (3) to (6), the estimation of the introduction of the multiplicative dummy dflex resulted in no statistically significant value. The same occurred with the additive dummy dthr in Eq. (7) and with the multiplicative dummy $d t h r$ for price elasticity, cross-price with respect to gasoline and income elasticity in the estimations (8) to (11) respectively. The only relevant change was verified in the cross-price elasticity with respect to ethanol, which declined from 0.096 to $0.034=(0.299)+(-0.265)$.

\subsection{Long-run elasticities}

Although the panel cointegration tests showed that there is no stable long-term equilibrium among the variables, the long-run elasticities were estimated in order to meet a reviewer. Table 7 shows the long-run elasticities based on the short-run interim partial effects, as described in Section 3. Standard errors presented in brackets were generated through the delta method (Oehlert, 1992).

As shown in the analysis above, the price elasticity of gasoline demand of -1.186 is close to Silva et al.'s (2009) estimate and implies that its consumers are elastic to price in the long-run. The other elasticities are lower than one, but show values distant from those of past studies. For ethanol demand, price elasticities of -8.465 , the cross-price with respect to gasoline of 7.991 and the income elasticity of 3.722 are considerably high and define highly elastic consumers regarding these 
Table 6

One-step GMM-Arellano-Bond short-run estimation of CNG demand for Brazil.

\begin{tabular}{|c|c|c|c|c|c|c|c|c|c|c|c|}
\hline CNG & (1) & $(2)$ & (3) & (4) & (5) & (6) & (7) & (8) & (9) & (10) & (11) \\
\hline Constant & $\begin{array}{l}-1.017^{*} \\
(0.184)\end{array}$ & $\begin{array}{l}-1.526^{*} \\
(0.255)\end{array}$ & $\begin{array}{l}-1.119^{*} \\
(0.205)\end{array}$ & $\begin{array}{l}-1.475^{*} \\
(0.235)\end{array}$ & $\begin{array}{l}-1.161^{*} \\
(0.193)\end{array}$ & $\begin{array}{l}-1.426^{*} \\
(0.235)\end{array}$ & $\begin{array}{l}-0.972^{*} \\
(0.187)\end{array}$ & $\begin{array}{l}-1.070^{*} \\
(0.193)\end{array}$ & $\begin{array}{l}-0.979 * \\
(0.185)\end{array}$ & $\begin{array}{l}-0.994^{*} \\
(0.184)\end{array}$ & $\begin{array}{l}-0.981^{*} \\
(0.186)\end{array}$ \\
\hline$\varepsilon_{c n g}$ & $\begin{array}{l}-0.178^{*} \\
(0.045)\end{array}$ & $\begin{array}{l}-0.194^{*} \\
(0.044)\end{array}$ & $\begin{array}{l}-0.107^{\mathrm{ns}} \\
(0.078)\end{array}$ & $\begin{array}{l}-0.192^{*} \\
(0.044)\end{array}$ & $\begin{array}{l}-0.178^{*} \\
(0.044)\end{array}$ & $\begin{array}{l}-0.193^{*} \\
(0.044)\end{array}$ & $\begin{array}{l}-0.178^{*} \\
(0.044)\end{array}$ & $\begin{array}{l}-0.121^{* * *} \\
(0.077)\end{array}$ & $\begin{array}{l}-0.179^{*} \\
(0.044)\end{array}$ & $\begin{array}{l}-0.186^{*} \\
(0.045)\end{array}$ & $\begin{array}{l}-0.178^{*} \\
(0.044)\end{array}$ \\
\hline$\varepsilon_{\text {cng.g }}$ & $\begin{array}{l}0.371^{*} \\
(0.162)\end{array}$ & $\begin{array}{l}0.356^{*} \\
(0.160)\end{array}$ & $\begin{array}{l}0.354^{*} \\
(0.162)\end{array}$ & $\begin{array}{l}0.238^{\mathrm{ns}} \\
(0.166)\end{array}$ & $\begin{array}{l}0.343^{*} \\
(0.162)\end{array}$ & $\begin{array}{l}0.348^{*} \\
(0.161)\end{array}$ & $\begin{array}{l}0.256^{\text {ns }} \\
(0.183)\end{array}$ & $\begin{array}{l}0.387^{*} \\
(0.163)\end{array}$ & $\begin{array}{l}0.260^{* * *} \\
(0.175)\end{array}$ & $\begin{array}{l}0.272^{* * *} \\
(0.167)\end{array}$ & $\begin{array}{l}0.248^{*} \\
(0.182)^{\mathrm{ns}}\end{array}$ \\
\hline$\varepsilon_{\text {cng.e }}$ & $\begin{array}{l}0.096^{\mathrm{ns}} \\
(0.095)\end{array}$ & $\begin{array}{l}0.106^{\mathrm{ns}} \\
(0.094)\end{array}$ & $\begin{array}{l}0.101^{\mathrm{ns}} \\
(0.094)\end{array}$ & $\begin{array}{l}0.106^{\mathrm{ns}} \\
(0.094)\end{array}$ & $\begin{array}{l}-0.133^{\mathrm{ns}} \\
(0.135)\end{array}$ & $\begin{array}{l}0.1094^{\mathrm{ns}} \\
(0.094)\end{array}$ & $\begin{array}{l}0.205^{\text {**** }} \\
(0.124)\end{array}$ & $\begin{array}{l}0.0696^{\mathrm{ns}} \\
(0.099)\end{array}$ & $\begin{array}{l}0.2327^{* *} \\
(0.124)\end{array}$ & $\begin{array}{l}0.298^{*} \\
(0.128)\end{array}$ & $\begin{array}{l}0.212^{* * *} \\
(0.123)\end{array}$ \\
\hline$\varepsilon_{I}$ & $\begin{array}{l}0.139 * \\
(0.064)\end{array}$ & $\begin{array}{l}0.061^{\text {ns }} \\
(0.068)\end{array}$ & $\begin{array}{l}0.128^{*} \\
(0.064)\end{array}$ & $\begin{array}{l}0.064^{\mathrm{ns}} \\
(0.067)\end{array}$ & $\begin{array}{l}0.113^{* * * *} \\
(0.064)\end{array}$ & $\begin{array}{l}0.0813^{\mathrm{ns}} \\
(0.066)\end{array}$ & $\begin{array}{l}0.135^{*} \\
(0.064)\end{array}$ & $\begin{array}{l}0.132 * \\
(0.064)\end{array}$ & $\begin{array}{l}0.133^{*} \\
(0.064)\end{array}$ & $\begin{array}{l}0.124^{*} \\
(0.064)\end{array}$ & $\begin{array}{l}0.131^{*} \\
(0.064)\end{array}$ \\
\hline$\Gamma$ & $\begin{array}{l}0.828^{*} \\
(0.016)\end{array}$ & $\begin{array}{l}0.802^{*} \\
(0.019)\end{array}$ & $\begin{array}{l}0.818^{*} \\
(0.019)\end{array}$ & $\begin{array}{l}0.799^{*} \\
(0.019)\end{array}$ & $\begin{array}{l}0.819 * \\
(0.017)\end{array}$ & $\begin{array}{l}0.804^{*} \\
(0.018)\end{array}$ & $\begin{array}{l}0.827^{*} \\
(0.016)\end{array}$ & $\begin{array}{l}0.824^{*} \\
(0.017)\end{array}$ & $\begin{array}{l}0.828^{*} \\
(0.016)\end{array}$ & $\begin{array}{l}0.830^{*} \\
(0.016)\end{array}$ & $\begin{array}{l}0.827^{*} \\
(0.016)\end{array}$ \\
\hline $\begin{array}{l}\Theta=(1-\gamma) \\
\text { Dflex }\end{array}$ & 0.172 & $\begin{array}{l}0.198 \\
0.073^{*}\end{array}$ & 0.182 & 0.201 & 0.181 & 0.195 & 0.172 & 0.176 & 0.172 & 0.169 & 0.172 \\
\hline Dflexpcng & & & $\begin{array}{l}-0.098^{\mathrm{ns}} \\
(0.088)\end{array}$ & & & & & & & & \\
\hline Dflexpgsll & & & & $\begin{array}{l}0.151^{*} \\
(0.049)\end{array}$ & & & & & & & \\
\hline Dflexpalc & & & & & $\begin{array}{l}0.315^{*} \\
(0.132)\end{array}$ & & & & & & \\
\hline Dflexincome & & & & & & $\begin{array}{l}-0.020^{*} \\
(0.007)\end{array}$ & & & & & \\
\hline Dthr & & & & & & & $\begin{array}{l}-0.031^{*} \\
(0.023)\end{array}$ & & & & \\
\hline Dthrpcng & & & & & & & & $\begin{array}{l}-0.08^{\mathrm{ns}} \\
(0.087)\end{array}$ & & & \\
\hline Dthrpgsls & & & & & & & & & $\begin{array}{l}-0.079^{* * *} \\
(0.046)\end{array}$ & & \\
\hline Dthrpalc & & & & & & & & & & $\begin{array}{l}-0.265^{*} \\
(0.113)\end{array}$ & \\
\hline Dthrincome & & & & & & & & & & & $\begin{array}{l}0.0098^{*} \\
(0.007)\end{array}$ \\
\hline Observations & 588 & 588 & 588 & 588 & 588 & 588 & 588 & 588 & 588 & 588 & 588 \\
\hline Wald-prob $>\chi^{2}$ & 0.000 & 0.000 & 0.000 & 0.000 & 0.000 & 0.000 & 0.000 & 0.000 & 0.000 & 0.000 & 0.000 \\
\hline
\end{tabular}

Note 1: The values in brackets refer to standard error.

Note 2: The symbols “*”, “**” and “***” refer to significance level at $1 \%, 5 \%$ and $10 \%$ respectively and "ns” refers to a non-significant parameter.

two fuels and also income. This happened because of the combination of a large magnitude of parameters " $\beta$ " and " $\gamma$ ". Although the flex-fuel technology makes the consumers more sensitive to price and that consumers belong to lower income groups, long-run elasticities regarding the demand for ethanol should be interpreted with caution until the development of new and specific research about the demand for ethanol in Brazil. Finally, for the CNG, the price elasticity of -1.034 (the same as the value found by Iootty et al., 2004), and cross-price elasticity with respect to gasoline of 2.159 show that consumers are price elastic regarding these two fuels in the long-run. This result, along with the low income elasticity of 0.809 , defines the behavior of consumers belonging to lower income groups, such as the consumers of ethanol.

\section{Final remarks}

This paper proposed an evaluation of the short-run and long-run sensitivity of fuel consumers to price and income prior to the recent

Table 7

Long-run elasticities for fuel demand in Brazil.

\begin{tabular}{llllll}
\hline Gasoline & \multicolumn{3}{c}{ Ethanol } & \multicolumn{3}{c}{ CNG } \\
\hline$\varepsilon_{g}$ & $-1.186^{*}$ & $\varepsilon_{e}$ & $-8.465^{*}$ & $\varepsilon_{\text {cng }}$ & $-1.034^{*}$ \\
& $(0.241)$ & & $(1.634)$ & & $(0.346)$ \\
$\varepsilon_{\text {g.e }}$ & $0.293^{*}$ & $\varepsilon_{\text {e.gsl }}$ & $7.991^{*}$ & $\varepsilon_{\text {cng.g }}$ & $2.159^{*}$ \\
& $(0.141)$ & & $(1.752)$ & & $(0.916)$ \\
$\varepsilon_{\text {g.cng }}$ & $0.028^{*}$ & $\varepsilon_{\text {e.cng }}$ & $0.664^{*}$ & $\varepsilon_{\text {cng.e }}$ & $0.560^{\text {ns }}$ \\
& $(0.089)$ & & $(0.349)$ & & $(0.481)$ \\
$\varepsilon_{I}$ & $0.523^{*}$ & $\varepsilon_{I}$ & $3.722^{*}$ & $\varepsilon_{I}$ & $0.809^{*}$ \\
& $(0.033)$ & & $(0.554)$ & & $(0.112)$ \\
\hline
\end{tabular}

Note: The symbols “*”, “***” and “***” refer to significance level at $1 \%, 5 \%$ and $10 \%$ respectively and "ns" refers to a non-significant parameter. changes in the Brazilian fuel market. The main features of this market were described. The previous strategy of producing ethanol to substitute fossil fuel, new market rules, the introduction of CNG and the flex-fuel technology have increased consumer choices and stimulated competition among fuels. The question that has emerged was: how sensitive are the consumers in this new environment? The econometric specification of a dynamic panel data model allowed estimating short and long-run price and income elasticities, as well as adjustment coefficients regarding the desired demand level. Additive and multiplicative dummies also allowed evaluating the introduction of flex-fuel and the rationality of consumers to the threshold of closeness of ethanol and gasoline prices.

The results for the short-run were supported by economic theory. Although the parameters are different, the gasoline demand equation can be compared to estimations of the literature. For the ethanol demand, the greater-than-one price elasticity and cross-price with respect to gasoline are also comparable to results in the literature and reflect a highly competitive fuel market due to the combination of the fuel diversification with the flex-fuel technology. The higher price elasticity for ethanol compared to gasoline and CNG, implied that ethanol consumers have more options in the occasion of price increases, whereas gasoline and CNG consumers are more vulnerable to price increases. The crossprice elasticities for the fuels determined different degrees of imperfect substitution among the three fuels, with variations depending on the estimated demand curve. Moreover, income elasticities ranked the demand for ethanol as the most income induced, followed by gasoline and CNG. Another important remark is that the adjustment coefficient demonstrates that the consumers are distant from the desired demand levels for all three fuels, which defines a market with a high potential of growth or diversification. 
Differently from other countries, the dynamics of the Brazilian fuel market is centered on ethanol instead of gasoline, while CNG has a marginal contribution for this dynamics. Although CNG competes with gasoline, there are signs of segmentation in the market and that it faces its own market conditions. As a consequence, CNG should be modeled independently in future studies. The ethanol demand curve was more responsive to prices and more distant from the desire demand level. Ethanol has strengthened its position as an independent fuel and a substitute for gasoline, mainly because of the growth of the fleet based on flex-fuel technology. For this reason, ethanol is considered to be one of the most important fuel regarding energy policy issues. However, this also suggests the necessity to maintain high levels of ethanol supply even when the national production is low, by importing this fuel, for example. Furthermore, ethanol consumers are becoming more responsive to price and the rationality test performed also indicates that the consumers consider technical restrictions of the flex-fuel engines when ethanol prices reach $70 \%$ of gasoline prices. This is a very positive aspect for the competitiveness of the fuel sector in Brazil.

Future studies could be carried out to study the specific demand for ethanol and compare different dynamic models using the stock of flex-fuel engines vehicles by states in Brazil. Future studies also need to be carried out to evaluate the adjustment of the flexible functional forms to quarterly data regarding the fuel demand in Brazil. Finally, the estimation using panel data models needs to be considered to evaluate different patterns of consumer behavior by region or states in Brazil as a starting point to evaluate the impacts of energy policies in the regional fuel market.

\section{Appendix A}

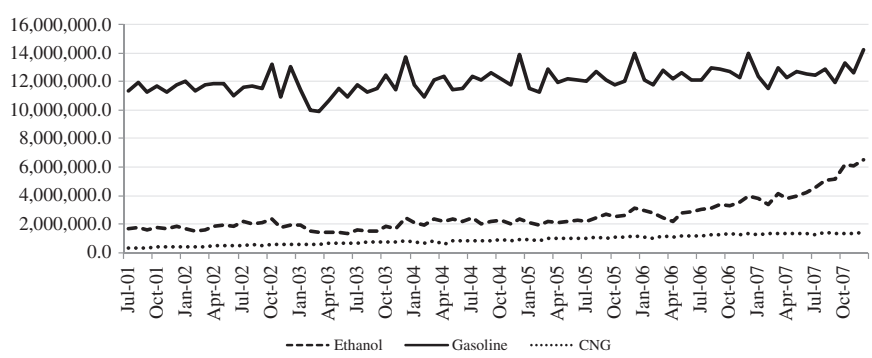

Fig. 5. Consumption of gasoline, ethanol and CNG in Brazil (in barrels). Source: ANP - Brazilian National Agency of Oil.

\section{Appendix B}

Table 8

Short-run estimation of price. Cross-price and income elasticities using a Translog model.

\begin{tabular}{llllll}
\hline Gasoline & \multicolumn{3}{c}{ Ethanol } & \multicolumn{3}{c}{ CNG } \\
\hline$\varepsilon_{g}$ & $-0.782^{*}$ & $\varepsilon_{e}$ & $-1.526^{\mathrm{ns}}$ & $\varepsilon_{\text {cng }}$ & $-0.021^{\mathrm{ns}}$ \\
& $(0.006)$ & & $(2.197)$ & & $(2.430)$ \\
$\varepsilon_{g . e}$ & $1.555^{*}$ & $\varepsilon_{\text {e.g }}$ & $1.181^{\mathrm{ns}}$ & $\varepsilon_{\text {cng.g }}$ & $0.324^{\mathrm{ns}}$ \\
& $(0.002)$ & & $(3.491)$ & & $(7.487)$ \\
$\varepsilon_{\text {g.cng }}$ & $-0.012^{*}$ & $\varepsilon_{\text {e.cng }}$ & $0.456^{* *}$ & $\varepsilon_{\text {cng.e }}$ & $0.165^{\mathrm{ns}}$ \\
& $(0.002)$ & & $(0.269)$ & & $(2.357)$ \\
$\varepsilon_{I}$ & $0.282^{*}$ & $\varepsilon_{I}$ & $0.536^{*}$ & $\varepsilon_{I}$ & $0.109^{* *}$ \\
& $(0.000)$ & & $(0.027)$ & & $(0.068)$ \\
\hline
\end{tabular}

Note 1: The values in brackets refer to standard error and were generated using the delta method.

Note 2: The symbols “*”, “**” and “**** refer to significance level at $1 \%, 5 \%$ and $10 \%$ respectively and "ns" refers to a non-significant parameter.

\section{References}

Alves, D.C.O., Bueno, R.L.S., 2003. Short-run, long-run and cross elasticities of gasoline demand in Brazil. Energy Econ. 25, 191-199.

Anderson, T.W., Hsiao, C., 1981. Estimation of dynamic models with error components. J. Am. Stat. Assoc. 76 (375), 598-606.

Anderson, T.W., Hsiao, C., 1982. Formulation and estimation of dynamic models using panel data. J. Econ. 18 (1), 47-82.

Arellano, M., Bond, S., 1991. Some tests of specification for panel data: Monte Carlo evidence and an application to employment equations. Rev. Econ. Stud. 58 (2), 277-297.

Azevedo, B.S., 2007. Análise das elasticidades preço e renda da demanda por combustíveis no Brasil e desagregadas por regiões geográficas. Dissertation in Economics. Ibmec, Rio de Janeiro, March.

Balestra, P., Nerlove, M., 1996. Pooling cross-section and time-series data in the estimation of a dynamic model: the demand for natural gas. Econometrica 34 (3), 585-612.

Baltagi, B.H., 2001. Econometric Analysis of Panel Data. John Wiley and Sons, Ltd., Chichester.

Baltagi, B.H., Griffin, J.M., 1983. Gasoline demand in the OECD: an application of pooling and testing procedures. Eur. Econ. Rev. 22 (2), 117-137.

Bentzen, J., 1994. An empirical analysis of gasoline demand in Denmark using cointegration techniques. Energy Econ. 16 (2), 39-143.

Brazilian Institute of Geography and Statistic (IBGE), 2011. Índices de preços e estimativas populacionais. http://www.ibge.gov.br.

Brazilian National Treasury, 2011. Arrecadação mensal dos estados. http://www.receita. fazenda.gov.br.

Breitung, J., 2000. The local power of some unit root tests for panel data. Advances in Econometrics. In: Baltagi, B.H. (Ed.), Nonstationary Panels, Panel Cointegration, and Dynamic Panels, vol. 15. JAY Press, Amsterdam, pp. 161-178.

Breitung, J., Das, S., 2005. Panel unit root tests under cross-sectional dependence. Statistica Neerlandica 59, 414-433.

Burnquist, H.L., Bacchi, M.R.P., 2002. A demanda por gasolina no Brasil: uma análise utilizando técnicas de co-integração. CEPEA, Discussion Paper. www.cepea.esalq.usp.br/pdf/DemandaGasolina.pdf.

Choi, I., 2001. Unit root tests for panel data. J. Int. Money Finance 20, 249-272.

Dahl, C., Sterner, T., 1991. Analyzing gasoline demand elasticities: a survey. Energy Econ. 13 (3), 203-210.

Dahl, C., 1995. Demand for transportation fuels: a survey of demand elasticities and their components. J. Energy Lit. 1 (2), 3-27.

Eltony, M.N., Al-Mutairi, N.H., 1995. Demand for gasoline in Kuwait: an empirical analysis using co-integration techniques. Energy Econ. 17 (3), 249-253.

Espey, M., 1996a. Explaining the variation in elasticity estimates of gasoline demand in the United States: a meta-analysis. Energy J. 17 (3), 49-60.

Espey, M., 1996b. Watching the fuel gauge: an international model of automobile fuel economy. Energy Econ. 18 (1-2), 93-106.

Espey, M., 1998. Gasoline demand revisited: an international meta-analysis of elasticities. Energy Econ. 20 (3), 273-295.

Freitas, L.C., Kaneko, S., 2011. Ethanol demand under the flex-fuel technology regime in Brazil. Energy Econ. 33 (6), 1146-1154.

Goodwin, P.B., Dargay, J., Hanly, M., 2004. Elasticities of road traffic and fuel consumption with respect to price and income: a review. Transp. Rev. 24 (3), 292-375.

Graham, D., Glaister, S., 2002. The demand for automobile fuel: a survey of elasticities. J. Transp. Econ. Policy 36, 1-26 (Part I).

Graham, D., Glaister, S., 2004. The responses of motorists to fuel price changes: a survey. Transp. Rev. 24 (3), 261-274.

Hadri, K., 2000. Testing for stationarity in heterogeneous panel data. Econ. J. 3, 148-161.

Harris, R.D.F., Tzavalis, E., 1999. Inference for unit roots in dynamic panels where the time dimension is fixed. J. Econ. 91, 201-226.

Hsiao, C., 1985. Benefits and limitations of panel data. Econ. Rev. 4 (1), 121-174.

Hsiao, C., 1986. Analysis of Panel Data. Cambridge University Press, Cambridge.

Im, K.S.M., Pesaran, H., Shin, Y., 2003. Testing for unit roots in heterogeneous panels. J. Econ. $115,53-74$

Iootty, M., Pinto Jr., H., Roppa, B., Biasi, G., 2004. Uma análise da competitividade preço do CNG frente à gasolina: estimação das elasticidades da demanda por CNG no Brasil no período recente. In: IE/UFRJ (Ed.), Rio Oil and Gas Expo and Conference. UFRJ, Rio de Janeiro.

Levin, A., Lin, C.-F., Chu, C.-S.J., 2002. Unit root tests in panel data: asymptotic and finite-sample properties. J. Econ. 108, 1-24.

Liu, G., 2004. Estimating energy demand elasticities for OECD countries: a dynamic panel data approach. Statistics Norway, Discussion Paper n. 373. http://www.ssb.no/ publikasjoner/DP/pdf/dp373.pdf.

Nappo, M., 2007. A demanda por gasolina no Brasil: Uma avaliação de suas elasticidades após a introdução dos carros bicombustível. Fundação Getúlio Vargas, Escola de Economia de São Paulo-EESP/FGV, Sao Paulo . (March).

National Agency of Oil and Biofuel (ANP), 2011. Levantamento mensal de preços e vendas de combustíveis no Brasil. http://www.anp.gov.br.

National Traffic Agency (DENATRAN), 2011. Frota nacional de veículos automotores. www. denatran.gov.br.

Nickell, S., 1981. Biases in dynamic models with fixed effects. Econometrica 49 (6), 1417-1426.

Oehlert, G.W., 1992. A note on the delta method. Am. Stat. 46 (1), 27-29.

Pesaran, M.H., Smith, R., 1995. Estimating long-run relationships from dynamic heterogeneous panels. J. Econ. 68 (1), 79-113.

Pindyck, R., Rotemberg, J., 1982. Dynamic factor demands under rational expectations. NBER Working Paper Series, 1015, p. 21. http://dspace.mit.edu/handle/1721.1/ 2022. 
Polemis, M., 2006. Empirical assessment of the determinants of road energy demand in Greece. Energy Econ. 28 (3), 385-403.

Pontes, A. P., 2009. Elasticidades de curto e longo praz os da demanda por álcool hidratado no Brasil. Thesis for the Graduate Program of Economics. UFPE, Recife

Puller, S., Greening, L., 1999. Household adjustment to gasoline price change: an analysis using 9 years of US survey data. Energy Econ. 21 (1), 37-52.

Rogat, J., Sterner, T., 1998. The determinants of gasoline demand in some Latin American countries. Int. J. Glob. Energy Issues 11 (1-4), 162-170.

Roppa, B.F., 2005. Evolução do consumo de gasolina no Brasil e suas elasticidades: 1973 a 2003. UFRJ, Rio de Janeiro.

Rouwendal, J., 1996. An economic analysis of fuel use per kilometer by private cars. J. Transp. Econ. Policy 30 (1), 3-14.

Sargan, J., 1958. The estimation of economic relationships using instrumental variables. Econometrica 26 (3), 393-415.
Schünemann, L., 2007. A demanda de gasolina automotiva no Brasil: o impacto nas elasticidades de curto e longo prazo da expansão do gnv e dos carros flex. Faculdades Faculdade de Economia e Finanças Ibmec, Rio de Janeiro.

Silva, G.F., Tiryki, G.F., Pontes, L.A.M., 2009. The impact of a growing ethanol market on the demand elasticity for gasoline in Brazil. 32nd Annual International Association for Energy Economics Conference, San Francisco.

Watkins, G.C., 1991. Short- and long-term equilibria: relationships between first and third generation dynamic factor demand models. Energy Econ. 13 (1), 2-9.

Westerlund, J., 2007. Testing for error correction in panel data. Oxf. Bull. Econ. Stat. 69 709-748.

Wooldridge, J., 2004. Econometric Analysis of Cross Section and Panel Data. MIT Press, USA. 